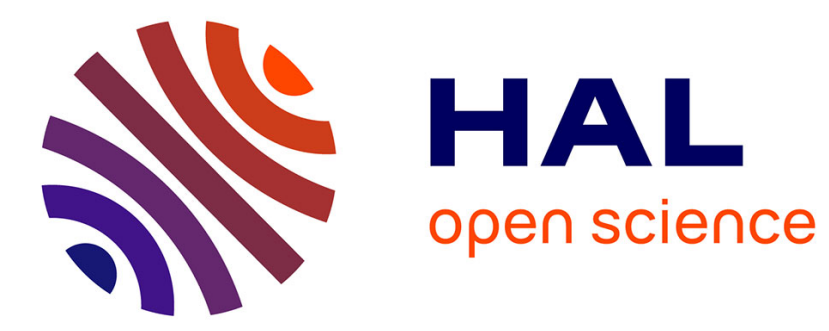

\title{
Competing discourses of workplace health
}

\author{
Steven Allender, Derek Colquhoun, Peter H. Kelly
}

\section{To cite this version:}

Steven Allender, Derek Colquhoun, Peter H. Kelly. Competing discourses of workplace health. Health:, 2006, 10 (1), pp.75-93. 10.1177/1363459306058989 . hal-00571419

\section{HAL Id: hal-00571419 \\ https://hal.science/hal-00571419}

Submitted on 1 Mar 2011

HAL is a multi-disciplinary open access archive for the deposit and dissemination of scientific research documents, whether they are published or not. The documents may come from teaching and research institutions in France or abroad, or from public or private research centers.
L'archive ouverte pluridisciplinaire HAL, est destinée au dépôt et à la diffusion de documents scientifiques de niveau recherche, publiés ou non, émanant des établissements d'enseignement et de recherche français ou étrangers, des laboratoires publics ou privés. 


\title{
Competing discourses of workplace health
}

\author{
Steven Allender, Derek Colquhoun \& \\ Peter Kelly \\ University of Oxford, UK, University of Hull, UK \& Monash \\ University, Australia
}

\begin{abstract}
This article presents an analysis of workplace health programme discourses within an international information technology company. Discourse refers to a system of statements that share a common force and coherence and which are socially constitutive. The representation of entities such as workplace health can be subject to competition between discourses. A critical discourse analysis was undertaken on semi-structured interviews, participant observation and workplace health programme documents. Two competing discourses were identified: health as safety and health as lifestyle. Each discourse is described and shown to both implicitly and explicitly define health within this particular workplace. Lifestyle discourse encouraged moves towards linking of the employees' working and private lives while safety discourse defined health in the relationship between workers and their physical environment. Competition between discourses both constricts and opens spaces for alternative understandings of health in the workplace. The implications of this competition for workplace health policy and practice are discussed.
\end{abstract}

KEYWORDS critical discourse analysis; discourse; lifestyle; occupational health; safety

AdDress Steven Allender, Department of Public Health, University of Oxford, Old Rd Oxford OX3 7LF, UK. [Tel: +44 (0)1865 226 837; fax:+44 (0)1865 226 720; e-mail: steven.allender@dphpc.ox.ac.uk]

\section{Introduction and background}

The increasing prevalence of workplace health programmes, workplace health consultants and private providers of workplace health services has made health at work a contentious topic. Despite health and work playing a central role in many of our lives the way in which workplace health programmes are constructed has not been critically examined. Modern workplace health is multidisciplinary, potentially involving occupational physicians, engineers, nurses, disability advisors, lifestyle coaches, lawyers, 
insurers, educationists, health and safety officers, health promoters, human resource managers, company directors, ergonomists, industrial hygienists and employees. While professional positions are generally taken for granted Cheek (2000) argues that, in any given setting, each competes for dominance, placing constraints on what can and cannot be thought, said or done. This article reports an analysis of the discourses competing in one such workplace health programme. Two competing discourses of workplace health were identified; health as safety discourse, supported by legislation; and, health as lifestyle discourse supported by broader social understandings of the impact of lifestyle on disease. The analysis of each discourse shows how they constitute knowledge and social practice and investigates the power relations inherent within them.

\section{Workplace health}

Apart from benefiting the health of the worker, occupational health contributes to productivity, product quality, work motivation and job satisfaction. Good workplace health programmes can provide a financial benefit to individuals, communities and countries. Conversely, the reduction in capacity due to work-related ill health in some countries equates to a loss of between 10 and $20 \%$ of GDP. Some estimates suggest that effective workplace health and safety programmes could prevent up to two-thirds of this loss in production (World Health Organization, 1995). In Australia, work-related injury and diseases cost the economy more than AUS $\$ 34$ billion in 2001-02, equivalent to 5\% of GDP. A further AUS $\$ 48$ billion is estimated to be lost in this country due to pain and suffering related to occupational illness and disease (National Occupational Health and Safety Commission, 2004).

\section{Current context of workplace health}

Organized programmes to protect the health of the workforce began in the Industrial Revolution. Some early interventions included physicians visiting mills, the guarding of machines and government inspection of factories (McCaig and Harrington, 1998). Since then, most developed countries have evolved comprehensive legislation to protect the safety of workers (Victorian Health and Safety Act, Victorian Parliament 1985). The introduction of health insurance as an employment condition in the USA established risk assessment and containment of ill-health costs as occupational health activities (Reardon, 1998). Further expansions in the health sciences provided increased professional standing to occupational health practitioners from fields of medicine, nursing, hygiene and economics. More recently, awareness of workplace health issues has increased in line with greater media and public interest.

The prevalence of workplace health programmes has increased in the 
past 10 years. A US study found that a quarter of small employers and almost half of large employers offered health promotion programmes to employees (Wilson et al., 1999). Earlier work by Hartwell et al. (1996) found that over a third of companies offered employee assistance programmes to their staff, representing an increase in programmes in the preceding decade.

The broad type of programme and scope for a wide range of specialist input suggests the potential for great variety in workplace health programmes. In a commonly cited review Chu and Forrester (1992) found Australian workplace health programmes varied widely from information leaflets posted on bulletin boards to company-wide individual health assessment and advice. Heaney and Goetzel's (1997) large survey in the USA found that all companies offered some form of health education, a number provided the opportunity to learn new skills and a minority intervened in work practices, organizational policy, or the physical working environment.

The variety in approaches to workplace health is mirrored in the numerous fields of workplace health research. Early workplace health research was concerned with the links between work-related exposure and disease. Such research was successful in establishing causal relationships between asbestos and mesothelioma, and benzene and some cancers. Economic research in the past 10 years has investigated the average cost per employee per year of programmes (Byers et al., 1995; Hartwell et al., 1996; French et al., 1999) and risk-related behaviour change following initiatives (Musich et al., 2003; Hanlon et al., 1996, 1998). More recent work has looked at the health behaviours of specific populations such as shift workers (Kaneko et al., 2004) and the effectiveness of new technologies in encouraging participation in programmes (Daly et al., 2005).

Workplace health research is characterized by its positivist nature and its focus on individual outcome measures such as cost per employee, behaviour change or disease incidence. Some authors advocate a further empirical shift towards randomized controlled trials of workplace health interventions (Heaney and Goetzel, 1997), while others argue for research from the employees' perspective. Although the current research agenda is valuable in its own right, it results in employees being researched upon, rather than with, resulting in what Colquhoun (1996) describes as an overly simplistic and naive representation of health.

The broad mix of interested parties involved in workplace health results in a complex, poly-vocal approach. Each professional standpoint brings a different set of understandings, methods and expectations to the idea of workplace health. These perspectives may often be competing, and some dominate while others are marginalized. Crofts (1998) argues that what is held to be 'true' in workplace health is hotly contested between employees, employers and other experts. None of these positions are value free or neutral, and each carry social and political meaning (Lupton, 1995). For employees, there may be mixed messages about what workplace health is, 
and what it means to be a healthy worker. The current framework appears to construe workplace health in terms of cost to the organization rather than a benefit to the employee. This raises a number of questions. How is health communicated and understood within workplace health programmes? What does health represent when portrayed by workplace health programmes? Which messages are important and which are not? What does it mean to be a healthy worker?

\section{Discourse analysis of workplace health}

A study of the communication and reception of health messages may be possible through the analysis of discourse (Potter and Wetherell, 1994). Discourse analysis allows for an examination of health communication and can show how 'different groups compete to shape the social reality of organisations in ways that serve their own interests' (Mumby and Clair, 1997: 182). Discourse can be understood as three levels of communication: as the general domain of all statements; as individualizable groups of statements; and as a 'regulated practice that accounts for a number of statements' (Mills, 1997: 7). Our discourse analysis approach takes a text of interest and examines the ways in which voices are heard or silenced, the authorities cited in the text and the conditions necessary for its production and reproduction (Fairclough, 1989; Fox, 1993; Fairclough and Wodak, 1997). Of interest here is the way in which discourses work; how certain ways of understanding health at work become accepted as normal; how the discourse legitimizes particular ways of seeing workplace health and deflects interest away from others; and how individuals and discourses are able to provide an alternative discourse and challenge the existing discourse.

Discourse analysis has uncovered the powerful effects of language in other work settings. Woollett and Marshall (1997) found that the institutional discourse of those working in maternity wards and antenatal clinics altered the behaviour of pregnant women and their families. A study of Asian and non-Asian mothers in London found that mothers were subjected to the competition from discourses located on one hand in established cultural beliefs and on the other in the practices and language of modern Western maternity care (Woollett et al., 1995). Western maternal discourse was shown to challenge traditional cultural beliefs with practical implications such as increasing the presence of Asian fathers at the birth of their children. Stenson and Watt (1999) studied local government texts with an interest in the meaning of the term 'social'. They found that the understanding of social was both complex and contested between the opposing logics of private enterprise and social government. The authors identify the tension between these approaches being played out in the competition between managerial and economic discourses. Earlier work by Nelkin (1985) touched on the constitutive power of language in a study of job uncertainty and risk. While discourse has been studied in a number of 


\section{Allender et al.: Competing Discourses of Workplace Health}

work settings, workplace health remains uncharted water for critical discourse analysis:

Few studies have looked specifically at the way in which a range of corporate ideas and discourses are combined within a given corporation's health and safety program ... very few have focused on the contradictory elements of corporate discourse and their implications for labour consent and resistance. (Hall, 1996: 98)

A discourse analysis of workplace health could help uncover the meanings and constructs of health at work and provide insight into the actions that follow. (White, 2004)

\section{Methods}

This case study aimed to identify and analyse the discourses of a workplace health programme. The study was set within a multi-national company called Labyrinth, ${ }^{1}$ which had 1300 employees across 160 sites in the Asia Pacific and was well known for the quality of its workplace health programmes. The company provided traditional programmes such as risk management, health and safety audit, accident investigation and workstation assessment. It also offered modern programmes such as health assessments, health and fitness sessions, 'quit smoking' classes and discounts for health insurance and gym membership. All company employees had free access to the company health programme as part of their employment agreement. A large portion of the health programmes were provided by an external contractor called 'Johns Health'.

Semi-structured interviews were conducted with the staff responsible for workplace health programmes and other general staff. Workplace health staff interviewed included the health programme manager, the safety officer, company nurses, the lifestyle programme manager and the director of Johns Health. General staff interviewed were two analyst programmers, two project managers, a systems programmer, a change manager and a records analyst. Participants were chosen using a snowball sampling technique beginning with the lifestyle programme manager. A referral from the lifestyles manager led to interviews with other health programme staff, general managers and other employees.

Interviews were recorded and later transcribed and participants were asked to review and edit their own transcripts. Over 40 interviews of between 30 minutes and 1 hour were conducted. Each interview began with the participant's description of health at Labyrinth and developed over the course of subsequent interviews. Interview questions diverged over second and third interviews between different participants. For example, the latter interviews with the safety officer related to maintenance of compliance to legislation, while interviews with the occupational health nurse included a discussion of health programme purchasing. 
Documents examined included the company's health policy, programme booklets, human resources databases, and internal and public company websites. More than 100 separate documents were included in the data corpus. Key among these were the nine health booklets provided to employees as part of the Johns Health programme.

Participant observation was undertaken by one researcher (SA) on a number of occasions. This included attending health lectures and programme planning meetings. The notes taken from this observation were used to inform the analysis but are not reproduced here. An Australian university provided ethics approval for this study.

The methodology for this analysis was critical discourse analysis (Fairclough, 1989; Janks, 1997). Analysis began with an initial reading of the data corpus to identify statements about workplace health at Labyrinth. Next, prescriptions and subject positions were identified and coded using the qualitative analysis software Atlas.ti. Subject positions were identified by asking who was being referred to, who was speaking and who the intended audience may be. Object positions were identified by asking what practices and objects defined each subject position in the data corpus. While Parker (1992) describes a progression from object to subject in discourse analysis as linear, we found starting with subject positions and building a picture of the objects around these more practical. Subject positions identified included employees, employers, the ill, managers, clients, experts and nonexperts. Safety and lifestyle were among the practices linked to these subjects.

By grouping like themes (subject and object), a coherent set of positions and prescriptions emerged. Discourse is a system of statements that constructs an object, which relies on a specific body of knowledge for its language and discipline (Foucault, 1972). These recurrent or 'patterned' statements formed the basis of the two specific discourses identified. The safety discourse was named for its unique set of prescriptions, such as slips and trips, machine guarding and so on. The lifestyle discourse was named for its generic concern with style of life, well-being and individual health behaviours.

We described the ways in which each discourse made specific subjects and objects visible or invisible, on how discourses legitimize some ways of seeing and marginalize others (Cheek, 2000). This part of the critical analysis focused on what could and could not be said, who could speak and who must listen, whose social constructions were valid and whose unimportant (Kincheloe and McLaren, 2000).

We have used discourse as the structure that links common statements with shared force and coherence, and which can be both socially constraining and constitutive (Mills, 1997). This social constructionist approach represents only one reading of the text and as such cannot make claims to any universal truth. The authors warn against attempting to generalize findings to other workplace health programmes. The following analysis 
describes the ways health as safety discourse and health as lifestyle discourse are represented through this workplace health programme. The implications of each discourse for the objective and subjective positioning of workplace health are described.

\section{Results and analysis}

Two dominant discourses were identified. These viewed workplace health as a function of either safety or of lifestyle. At any one particular time one of these discourses would be in the ascendancy (that is, seen as more important by employers and employees alike). Our analysis was interested in who could and could not speak for each discourse, what could and could not be said and whose social constructions were valid. Table 1 illustrates each discourse against this framework.

\section{Who can speak?}

Safety and health are produced as two exclusive approaches to workplace health. There is tension between the two discourses as practitioners stake their territory by marginalizing alternative views. Safety officer Amber

Table 1 Competing discourses of workplace health

\begin{tabular}{|c|c|c|}
\hline Workplace health & Health as safety & Health as lifestyle \\
\hline Who can speak & $\begin{array}{l}\text { Safety experts } \\
\text { Governments through } \\
\text { legislation }\end{array}$ & $\begin{array}{l}\text { Fitness experts } \\
\text { Multiple voices }\end{array}$ \\
\hline Who cannot speak & $\begin{array}{l}\text { The injured } \\
\text { Health professionals } \\
\text { Employees }\end{array}$ & $\begin{array}{l}\text { The unwell, disabled } \\
\text { Safety professionals } \\
\text { Employees }\end{array}$ \\
\hline What can be said & $\begin{array}{l}\text { Health is a legal concern } \\
\text { Health is a result of safe } \\
\text { working environments } \\
\text { Workplace hazards are a threat } \\
\text { to health } \\
\text { Ill health results from accidents }\end{array}$ & $\begin{array}{l}\text { Lifestyle influences performance } \\
\text { Health is affected by many things } \\
\text { Attitudes and behaviours are a } \\
\text { threat to health }\end{array}$ \\
\hline What cannot be said & $\begin{array}{l}\text { Health is a personal resource } \\
\text { Illness may not be the result of } \\
\text { an accident }\end{array}$ & $\begin{array}{l}\text { Work/social conditions affect } \\
\text { health }\end{array}$ \\
\hline $\begin{array}{l}\text { Whose social } \\
\text { constructions are } \\
\text { valid }\end{array}$ & $\begin{array}{l}\text { Safety experts (inspectors, } \\
\text { officers) } \\
\text { Detailed records }\end{array}$ & $\begin{array}{l}\text { Physical fitness professionals } \\
\text { Medical professionals }\end{array}$ \\
\hline
\end{tabular}


shows that qualifications are clear markers for who can and cannot speak with authority for safety discourse:

Safety issues are different to health issues so I guess how you manage them, you don't need to have someone who's a health professional to manage health related issues. I mean you can probably have somebody with no particular health background manage it.

Safety discourse constructs other approaches to health at work as quasiprofessional, requiring no specific qualification. This stance is rationalized by safety discourse in the need for professional input and technical expertise. The health as lifestyle discourse uses the same technique to define and distance itself from safety discourse. Johns Health director Herbert Johns describes the lack of professional qualifications among safety officers:

Yeah well see there's no good physical educators in industry, they're just clerical officers who have taken over occ health and safety. It's shameful, most of them aren't trained in occ health and safety, or if they have been to occ health and safety courses their piss fartin' courses, or if they've done tertiary courses on it none of them have anything to do with health or fitness. It's all fuckin' safety.

Each discourse makes clear who can and cannot speak about health. Each discourse position presents a professional qualification as justification for their input, and derides other approaches for a lack of qualifications. For safety discourse, it must be a safety professional talking about health at work. For lifestyle discourse, physical educators can talk about health and someone less qualified can speak about safety.

\section{What can be said - safety discourse?}

The legislative support for safety discourse provides a strong foothold in workplace health. Amber describes the influence of legislation on the company's approach:

The way I look at it, and I guess the way most health and safety professionals would look at it is that you have to determine what does the company legally have to do, what are our responsibilities? We do have very clear-cut responsibilities in law about a number of aspects of health, and they are for example, exposure to chemicals at work is heavily legislated so there are some key responsibilities on any company and in that they would feature that the employee has a shared responsibility to use the information about safely managing chemicals to protect their own health.

Legislation legitimizes safety discourse and marginalizes lifestyle discourse. Here Amber describes the difference between her role as a safety officer and that of the healthy lifestyles programme manager:

Mine is on the stuff the company has to do in terms of meeting its legal and moral obligations to providing a safe workplace. Hers [healthy lifestyles 
manager] is more about what the company can do to make working life better, so it's the what we'd like to do's not the have to do's.

For safety discourse, health is compliance to law and anything else is an unnecessary extra. Legislation helps safety discourse build a position of dominance and silences alternative approaches to health. Records analyst Libra tried to introduce lunchtime Tai Bo (a mix of aerobics and shadow boxing) sessions for herself and other interested staff:

We tried to bring Tai Bo into the seminar room, someone had a video, and the manager said 'No. Health and safety. If we injure ourselves and everything else.'

Within the company, there is a very clear demarcation between health as safety and health as lifestyle discourses. Amber, the company's safety officer describes the organization's approach to workplace health issues:

Ok well we've got this issue and how do we manage it? Ok well we look at it from a health perspective and a safety perspective, so it's mainly perspective rather than approach. Because we're all, in health and safety the key way in which you manage a hazard is actually identify and say 'well what is the hazard? Ok, it's alcohol. That's the hazard and how you assess the risk and manage the risk and evaluate the success in that would probably be the same if you were a safety or a health professional.

Intervention begins with identification of a specific hazard. The interaction between the employee and the hazard becomes the substance to be managed, regulated and governed. Compliance to safety discourse is practised through various forms of assessment and record keeping. One particular example is Amber's occupational health and safety checklist:

It's a checklist, which goes through some items that they would need to be aware of. Basically it's just like a health and safety review. It's like, look at your housekeeping, look at your lighting, your ergonomics, your materials handling, storage of materials. There are a whole lot of different things on it and it's a couple of page checklist. We basically ask them to look at it and note if there's any issues and actually action those issues.

Safety discourse uses detailed checklists to make health visible as the interaction between any employee and the hazards of the working environment. Poor health is determined by the physical workspace and comes from slips and trips, poor lighting, bad ergonomics and unsafe storage of materials. Health is not a personal resource, but the interaction between any employee and their workspace.

\section{What can be said - lifestyle discourse}

In contrast to the legislative focus of safety discourse, lifestyle discourse is multiple and varied. While safety discourse is concerned with specific, discrete physical exposures to harmful agents within the workplace, lifestyle discourse takes an interest in a wide array of aspects of the worker's life in the name 
of workplace health. The extensive range of services available to employees is shown in this text from the Healthy Lifestyles programme booklet:

HEALTHY LIFESTYLES CONSISTS OF THE FOLLOWING PROGRAMS:

Purchasing Service, Elder Care Information, Financial Planning, Families at Work Program, Home Loans, Car Loans, Savings and Credit Facilities, Health Plan Coverage. Discount Broking and Investment Services. Cinema Tickets, Tax and Legal Assistance Help Line, Travel Discount Program, Employee Assistance Program (EAP), Social Activities, Health Promotion Program.

THESE PROGRAMS WILL ENSURE THAT YOU AND YOUR FAMILY are given the opportunity to balance your work and personal life, have the ability to save time, are able to make dollar savings, are provided with information in managing your personal and financial affairs.

Lifestyle discourse incorporates elements as diverse as purchasing services, elder care, home loans and health promotion. This blurs the work and nonwork boundary by making more and more areas of the employee's life visible. Facilities such as savings and credit, home loans, purchasing services and travel discounts place workplace health in the employee's life outside work. At the same time, employees are encouraged to make their personal lives available to workplace health. Systems programmer Bob provides one example:

If you were going through a personal crisis they [work] will organise a counsellor, or a psychotherapist or even a psychiatrist or whatever you need.

The lifestyle discourse prescribes expectations for the conduct of the employee's private life. Those who can demonstrate physical fitness are valorized by their ability to work harder and be more productive. Analyst programmer William gives one example:

Certainly being healthy physically makes it easier to be healthier mentally. It makes concentration, I spent two hours this morning sitting at a PC, at 5 o'clock in the morning and there's not many people who can do that two hours straight.

Providing services normally reserved for private life such as cinema tickets and car loans increases available time. For lifestyle discourse this is time when the employee can work. By making private life visible to health at work, time outside the workplace becomes subject to the workplace as a whole. Thus private time becomes time where the employee can demonstrate their health by being more productive. This restructuring of working and private life is achieved by offering multiple concepts of health at work regardless of the barrier between the two. Lifestyle programme provider Herbert Johns describes the multiple possibilities of lifestyle discourse:

It's [workplace health] got to be holistic, anything that happens to you is rarely uni-causal, there is a whole lot of causes, there is a whole lot of things you need to fix up, and a lot of those things you need to fix up are probably in your head as well as in your body. 
Lifestyle discourse aims not just to improve employees' health, but also to produce more productive, profitable workers. Healthy lifestyles administrator Lyn identifies a direct link between the lifestyle programme and the health of the company:

I believe that's just really gonna make people fitter and more conscious of their health. Fitter workforce, better, fitter and healthier. Yeah, improvements for the company.

Lifestyle discourse ignores the influence of working conditions on health, locating health in the behaviour of individual employees. Worker health becomes tied directly to the health of the company. The healthy lifestyles programme booklet presents the Venn diagram in Figure 1 to employees.

This text explains clearly that a healthy organization requires healthy employees. The desirable employee is fit, healthy and presents a low risk to the company. Personal health, organizational health and career advancement are all linked by this text. This example of lifestyle discourse contains healthy people and healthy organizations; the ill or disabled are not represented.

\section{Social construction of workplace health}

Safety discourse uses the pressure to conform to powerful legislative requirements to validate its dominant position in workplace health. A safety qualification legitimizes intervention and allows safety experts to define health at work. Lifestyle discourse is marginalized by its lack of legislative backing and its multiple, fragmented nature. Herbert Johns describes the relative importance of the two approaches:

Well to be honest gimmicks are really popular. It's a thrill, what we do. People consider it a thrill. They do have an obligation to tell people probably about noxious fumes, they might have one for manual handling technique if it's a workshop, they might have one for climbing up and down ladders and slipping

Our approach to OH\&F is underpinned by the belief that people who are fit and healthy, who have a clear idea of what they want for their lives and their careers, and who are on the way to getting what they want, feel good, and the risk of employing them is low. They contribute to the vitality and productivity of themselves and their organization.

PERSONAL AND CORPORATE WELL-BEING

Things go well at work when youre going well. When you're not going well, the personal cost is high and so is the cost to the organization.

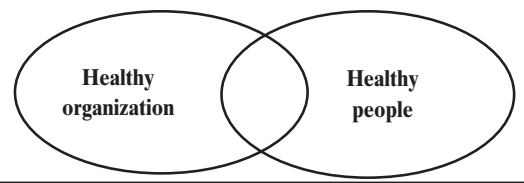

Figure 1 Introduction to occupational health and fitness (OH\&F) from Labryrinth. 
on slippery floors if it's a workshop, but apart from that you don't have to do anything.

The multiple nature of lifestyle discourse results in workplace health programmes with mixed aims, unclear objectives and unpredictable results. Employees often greet these initiatives with suspicion and mirth. Records Analyst Libra describes one instance:

One manager in the building wanted to run Alcoholics Anonymous, on alcohol abuse and when everybody found out they said 'I'll go to abuse alcohol'. It was seen as a bit of a joke.

This marginalization of non-safety discourse has implications for the employee's understandings of ill health. Libra describes one of her work colleagues:

Well there is one girl that's constantly been away sick, and it's become a joke among everybody else. I don't actually know what's wrong with her. But it's been happening the last couple of years. She's very slight anyway so perhaps she does catch colds but it's become this big joke.

There is no officially sanctioned role for the ill in either of the company's workplace health discourses. Thus there is no frame of reference for members of the organization to understand those colleagues who fall ill. The company's occupational health nurse describes the way management see her clients:

Illness is weakness, she deals with the weak, she deals with the people who can't cope and are therefore losers and I might catch it. There's no evidence that the organisation takes any responsibility for the effects, there is no organisational responsibility.

The two discourses reviewed produce unique constructions of health at work. For safety discourse, workplace health is located in the relationship between employees and their physical environment. For lifestyle discourse, workplace health is a function of behaviours whether the employee is at home or at work. In each discourse the ill are invisible or seen by others as a 'joke'. Each discourse confers the right to speak about health at work to specialists based on their qualifications. In this way, each discourse actively removes the right for others, such as employees, to speak.

\section{Discussion}

This case study of the discourses of workplace health in one IT company identified two competing discourses; health as safety and health as lifestyle. Each discourse constructed contesting versions of health at work. Safety discourse focused on the interaction of employees with their physical working space while lifestyle discourse was concerned with employee behaviour both inside and outside working hours. The legislative support 
of health as safety discourse provided it with a dominant position and forced employee compliance to particular forms of workplace health. All employees and managers were required to be aware of safety risks and their responsibility to maintain safe practices. Lifestyle discourse was devalued by its multiple nature and marginalized by the legislative strength of safety discourse. Common to each was the role of the worker as passive and compliant to experts from within either discourse.

\section{Role of the employee}

Health as safety discourse constructs workplace health as complex and confusing, requiring the interpretation and defusing of dangerous situations by experts. The worker is simply located in a dangerous environment, which they are not equipped to understand. The lack of an active role for employees at Labyrinth is echoed in Little et al. (2003) work on discourse communities in health care. Here, patients described themselves as 'victims of circumstance', generally inactive in relation to their health and reliant on input from expert practitioners.

Health as lifestyle discourse constructs workplace health without regard for time or space. Diet, sleeping patterns, thoughts and feelings are all considered open to workplace health and serve to make the employee visible outside work. This intrusion is rationalized on the effect poor health has on the organization. Fullagar (2002) describes healthy lifestyles as an ethical project and shows how it may incite people to behave in certain ways. Lifestyle discourse makes all aspects of the employee's working and private life visible at all times. In this way they are always under the gaze of the workplace health programme. This resonates with the notion of the panopticon (Foucault, 1977) in which prisoners who felt under constant surveillance began to discipline themselves. In making life outside work visible, lifestyle discourse forces employees to discipline themselves in the name of health both inside and outside work in terms of diet, sleeping patterns and so on. Another example of health as an ethical project is given by Kelly and Colquhoun (2003). Their study of Australian schools argues that the need to 'be professional' and manage stress recasts the relationship between teachers, head teachers and the education system. These authors identified an explicit relationship between being a professional and being healthy. Given this scenario, teachers willingly subjected themselves to stress-management practices with the aim of being recognized as 'professional'.

The meaning of terms like 'professional' and 'work' is changing. Lewis (2003) argues that in post-industrial society, work becomes indistinguishable from leisure. Her study of chartered accountants shows that freedom posed as personal choice over working conditions results in increased work hours for employees. The argument goes that freedom to be flexible in the way that people work actually increases the time spent working. Employees feel an ethical pressure to complete tasks rather than work within a 
particular working hours framework. This finding is echoed in the participants in this study who linked being healthy with being able to work longer hours. Health initiatives such as work-life balance have emerged within the spaces opened up by the possibilities for new ways of working. Perhaps more alarming is the stance of human resources authors such as Polach (2003) who argue that the next move is towards work-life integration, in which life can be managed to optimize working time and organizational effectiveness.

\section{Legislating for workplace health}

The success of health as safety discourse in colonizing the workplace could serve as a model toward other approaches to workplace health. Legislating for behaviour change or diet could also increase the visibility of the influence of lifestyle on workplace health and force workers and workforces to focus their attention. Townsend and Bennett (2003) suggest the current restructuring of work presents an opportunity to revisit workplace health legislation. These authors argue that existing employment regulations have become disconnected from the working conditions of a large proportion of the workforce. Legislating for health behaviour change has been conceived as a two-edged sword, on one hand promoting health but on the other carrying the potential to remove freedom. It involves an a priori assumption that all members of a population understand health and ill health in the same way. This is clearly false, for example arguments regarding legislation banning smoking completely would be welcomed by some and hotly opposed by others. Indeed, as Proctor's analysis of health promotion initiatives in Nazi Germany shows, legislation can go to extreme lengths in enforcing healthy behaviour within populations (Proctor, 1996, 1999).

\section{Rethinking approaches to health at work}

It is arguable whether current approaches to health at work are effective. This research has identified one company where two approaches are competing over workplace health. This competition may affect the efficacy and relevance of employee health programmes. One reasons for this may be the 'top-down' expert-led approach to programme design. A reorienting of workplace health programmes to include employees in the design, implementation and evaluation of programmes could help to address this. The idea of involving communities in health programmes is not new and authors such as Sen (1994) proposed programmes in which community members are involved at all stages of the health care process.

Implementing such programmes is not necessarily easy and early attempts at community empowerment have been heavily criticized (Madan, 1987; Watt and Rodmell, 1987). Sen (1994) found that the main barrier to empowering individuals was unwillingness to challenge organizations, officials and administrators. This finding reflects a significant challenge in 
an environment such as workplace health requiring great forethought and leadership on behalf of management. Additionally, health professionals must alter their approach and be prepared to concede power over interventions and move toward an advocacy and advisory role (Kennedy, 2001).

The entrenched discursive positions found in this case study suggest that reorienting health professionals in workplace health would be difficult, but empowering employees in health offers a lot to the workplace. Benefits noted in other settings from this approach included greater inter-agency working, wider acceptance of programmes to improve health and multidisciplinary forums for discussing health issues (Kennedy, 2001). The last in particular is relevant to the workplace represented in this study where two competing discourses reflect the varied groups with an interest in workplace health. Including workers in the design of programmes increases the programme's relevance by involving those with first-hand experience of the particular workplace. This 'first-hand' knowledge is particularly important in the new working environments presented by telecommuting and global working (Healy, 2000; Herbert, 1998).

Discourse analysis can offer some insight into the construction of workplace health within one company and generates a number of interesting questions. Although 'occupational health and safety' is used as a generic term for health at work, the two approaches are clearly separate. It appears that there is competition between practitioners and their discourses. Does this competition have implications for workplace health outcomes? Would employees engage more with other approaches (such as action research) to workplace health? These are areas that would benefit from further research and work needs to be done in conceiving approaches to workplace health that are less oppositional.

The workplace is one setting in many of our lives where personal, social and cultural interaction occurs. Within both discourses the workforce becomes governable as a single population, subject to expert opinion and deferential to professional knowledge.

\section{Conclusion}

It was possible to identify two discourses competing for dominance over one workplace health programme. The two discourses identified - health as lifestyle and health as safety - were found to marginalize employees who were ill or perceived as unproductive. Each discourse employed various tactics, such as defining the right to speak in relation to professional qualifications, to support their importance to workplace health. Health as safety discourse located health in the relationship between the body of the individual and the specific hazards of the working environment. Health as lifestyle discourse took a broad approach to the notion of health at work and included the employees' private lives in the remit of workplace health. The findings of this article suggest that the competition between these 
discourses may have negative implications for the practice of workplace health and thereby the health of workers.

\section{Note}

1. All names have been changed to protect anonymity.

\section{References}

Byers, T., Mullis, R., Anderson, J., Dusenbury, L., Gorsky, R., Kimber, C., Kreuger, K., Kuester, S., Mokdad, A., Perry. G. and Smith, C. (1995). The costs and effects of a nutritional education program following work-site cholesterol screening. American Journal of Public Health, 85, 650-5.

Cheek, J. (2000). Postmodern and poststructural approaches to nursing research. Thousand Oaks, CA: SAGE Publications.

Chu, C. and Forrester, C. (1992). Work place health promotion in Queensland. Brisbane: Queensland Health.

Colquhoun, D. (1996). Moving beyond biomedical research in health promotion. In D. Colquhoun and A. Kellehear (Eds.), Health research in practice: Personal experiences, public issues volume 2, pp. 30-49. London: Chapman and Hall.

Crofts, N. (1998). What do doctors really know? Australian Society, February, $39-54$.

Daly, J., Licata, M., Gillham, K. and Wiggers, J. (2005). Increasing the health promotion practices of workplaces in Australia with a pro-active telephone based intervention. American Journal of Health Promotion, 19, 163-6.

Fairclough, N. (1989). Language and power. London: Longman.

Fairclough, N. and Wodak, R. (1997). Critical discourse analysis. In T. van Dijk (Ed.), Discourse as Social Interaction, pp. 258-84. London: SAGE Publications.

Foucault, M. (1972). The archeology of knowledge. London: Routledge.

Foucault, M. (1977). Discipline and punish. London: Tavistock.

Fox, N. (1993). Postmodernism, sociology and health. Buckingham: Open University.

French, M.T., Zarkin, G.A., Bray, J.W. and Hartwell, T.D. (1999). Cost of employee assistance programs: Comparison of national estimates from 1993 and 1995. Journal of Behavioural Health Services and Research, 26, 95-103.

Fullagar, S. (2002). Governing the healthy body: Discourses of leisure and lifestyle within Australian health policy. health: An Interdisciplinary Journal for the Social Study of Health, Illness and Medicine, 6, 69-84.

Hall, A. (1996). The ideological construction of risk in mining: A case study. Critical Sociology, 22, 93-115.

Hanlon, P., Carey, L., Tannahill, C., Kelly, M., Gilmour, H., Tannahill, A. and McKewan, J. (1998). Behaviour change following a workplace health check: how much change occurs and who changes? Health Promotion International, 13, 131-9.

Hanlon, P., McEwan, J., Carey, L., Gilmour, H., Tannahill, C., Tannahill, A. and Kelly, M. (1996). Health checks and coronary risk: further evidence from a randomised controlled trial. British Medical Journal, 312, 974.

Hartwell, T.D., Steele, P., French, M.T., Potter, F.J., Rodman, N.F. and Zarkin, G.A. (1996). Aiding troubled employees: The prevalence, cost, and characteristics of Employee Assistance Programs (EAPs) in the United States. American Journal of Public Health, 86, 804-8. 


\section{Allender et al.: Competing Discourses of Workplace Health}

Healy, M.L. (2000). Telecommuting: Occupational health considerations for employee health and safety. American Association of Occupational Health Nurses Journal, 48, 305-13.

Heaney, C. and Goetzel, R. (1997). A review of health-related outcomes of multi-component worksite health promotion programs. American Journal of Health Promotion, 11, 290-307.

Herbert, M.A. (1998). Impact of IT on health care professionals: changes in work and the productivity paradox. Health Services Management Research, 11, 69-79.

Janks, H. (1997). Critical discourse analysis as a research tool. Discourse, 18, 329-42.

Kaneko, S.Y., Maeda, T., Sasaki, A., Sato, A., Tanaka, K., Kobayashi, T., Tanaka, M. and Fukushima, T. (2004). Changes in health habits of female shift workers. Journal of Occupational Health, 46, 192-8.

Kennedy, L.A. (2001). Community involvement at what cost? Local appraisal of a pan-European nutrition promotion programme in low-income neighbourhoods. Health Promotion International, 16, 35-45.

Kincheloe, J. and McLaren, P. (2000). Rethinking critical theory and qualitative research. In N. Denzin and Y. Lincoln (Eds.), Handbook of qualitative research (2nd edn), pp. 279-314. California, CA: SAGE Publications.

Kelly, P. and Colquhoun, D. (2003). Governing the stressed self: teacher 'health and wellbeing' in 'effective schools'. Discourse, 24, 191-204.

Lewis S. (2003). The integration of paid work and the rest of life. Is post industrial work the new leisure? Leisure Studies, 22, 343-55.

Little, M., Jordens, C.F.J. and Sayers, E. (2003). Discourse communities and the discourse of experience. health: An Interdisciplinary Journal for the Social Study of Health, Illness and Medicine, 7, 73-86.

Lupton, D. (1995). The Imperative of Health: Public Health and the Regulated Body. London: SAGE Publications.

McCaig, R. and Harrington, M., Eds. (1998). The Changing Nature of Occupational Health. London: Health and Safety Executive.

Madan, T.N. (1987). Community involvement in health policy: socio-structural and dynamic aspects of health beliefs. Social Science and Medicine, 25, 615-20.

Mills, S. (1997). Discourse: The new critical idiom. London: Routledge.

Mumby, D. and Clair, R. (1997). Organisational discourse. In T. van Dijk (Ed.), Discourse as Social Interaction, pp. 181-205. London: SAGE Publications.

Musich, S., McDonald, T., Hirschland, D. and Edington, D.W. (2003). Examination of risk status transitions among active employees in a comprehensive worksite health promotion program. Journal of Occupational and Environmental Medicine, 45, 393-9.

National Occupational Health and Safety Commission. (2004). The cost of work-related injury and illness for Australian employers, workers and the community. Canberra: Commonwealth of Australia.

Nelkin, D. (1985). The Language of risk. London: SAGE Publications.

Parker, I. (1992). Discourse dynamics: Critical analysis for social and individual psychology. London: Routledge.

Polach, J. (2003). HRD's role in work-life integration issues: Moving the workforce to a change in mindset. Human Resources Development International, 6, 57-68.

Potter, J. and Wetherell, M. (1994). Analyzing discourse. In A. Bryman and R. Burgess (Eds.), Analyzing qualitative data, pp. 47-66. London: Routledge. 
Proctor, R.N. (1996). The anti-tobacco campaign of the Nazis: A little known aspect of public health in Germany, 1933-45. British Medical Journal, 313, 1450-3.

Proctor, R.N. (1999). Why did the Nazis have the world's most aggressive anti-cancer campaign? Endeavour, 23, 76-9.

Reardon, J. (1998). The history and impact of worksite wellness. Nursing Economics, 16, 117-21.

Sen, R. (1994). Building community involvement in health care. Social Policy, 24, 32-43.

Stenson, K. and Watt, P. (1999). Governmentality and 'the death of the socia'? A discourse analysis of local governement texts in South-East England. Urban Studies, 36, 189-201.

Townsend, A.M. and Bennett, J.T. (2003). Information technology and employment law: Challenges in an evolving workplace. Journal of Labour Research, 24, 425-35.

Watt, A. and Rodmell, S. (1987). Community involvement in health promotion: Progress or panacea? Health Promotion, 2, 259-368.

White, R. (2004). Discourse analysis and social constructionism. Nurse Researcher, 12, 7-16.

Wilson, M.G., DeJoy, D.M., Jorgensen, C.M. and Crump, C.J. (1999). Health promotion programs in small worksites: Results of a national survey. American Journal of Health Promotion, 13, 358-65.

Woollett, A., Dosanjh, N., Nicolson, P., Marshall, H., Djhanbakhch, O. and Hadlow, J. (1995). The ideas and experiences of pregnancy and childbirth of Asian and non-Asian women in east London. British Journal of Medical Psychology, 68, 65-84.

Woollett, A. and Marshall, H. (1997). Discourses of pregnancy and childbirth. In L. Yardley (Ed.), Material discourses of health and illness, pp. 176-198. London: Routledge.

World Health Organization (1995). Global Strategy on Health for All: The Way to Health at Work: Recommendations of the Second Meeting of the WHO Collaborating Centres in Occupational Health. Geneva: WHO.

Victorian Parliament (1985). Occupational Health and Safety Act 1985. Melbourne: Victorian Parliament.

\section{Author biographies}

STEVEN ALLENDER is a senior researcher with the BHF Health Promotion Research Group at the University of Oxford. He manages the Coronary Heart Disease Statistics project and is developing research on childhood obesity and life course approaches to physical activity. He has a $\mathrm{PhD}$ in Sociology and experience in qualitative and quantitative research methods. From 2002 until 2005 he worked on an MRC project investigating long-term symptoms and current quality of life among human participants in chemical weapons tests at Porton Down. He has also worked on an HEFCE-funded project on occupational health service provision in UK universities.

DEREK COLQUHOUN holds the first Chair in Urban Learning in England. He is currently the Director of Research for the Institute for Learning at the University of Hull. Derek has previously researched and taught in Health Education and 
Health Promotion at Deakin University as well as at the University of Ballarat and Victoria University in Melbourne. In the past his research interests centred on the concept of the Health Promoting School for which he was awarded a WHO Research Scholarship to research with schools in Denmark. More recently Professor Colquhoun has been researching in the area of governmentality and complex adaptive systems. He is currently leading evaluations of several healthy schools award schemes in England as well as a project investigating the relationship between the provision of free healthy school meals and health, attainment and social capital for primary age children across the City of Hull.

PETER KELLY is the Head of Behavioural Studies at Monash University. From 2002 to 2005 he was a senior lecturer in Organizational Behaviour and Organizational Theory in the Faculty of Business and Law, Deakin University. Prior to this (1999-2002), he was a lecturer in the Behavioural Studies Program in the Faculty of Social and Behavioural Sciences at the University of Queensland. Current research interests include the New Work Ethics project exploring the emergence of new work identities, obligations, and responsibilities in a globalized risk economy, and the ways these concerns find expression in discussions about professionalization, work-related stress and work-life balance. 